\title{
Competitiveness and Unemployment in the Eurozone
}

\author{
Antonin Rusek ${ }^{1}$ \\ 1 Susquehanna University, Selinsgrove, USA \\ Correspondence: Antonin Rusek, Susquehanna University, Selinsgrove, PA 17870, USA. Tel: 570-372-4182. \\ E-mail: Rusek@susqu.edu
}

Received: January 19, 2015

Accepted: February 3, 2015

Online Published: March 25, 2015

doi:10.5539/ijef.v7n4p99

URL: http://dx.doi.org/10.5539/ijef.v7n4p99

\begin{abstract}
The paper analyzes the long term dynamics of the relationship between the competitiveness and the unemployment in the Eurozone, with the emphasis on the "North" and "South" differences. Using the productivity per person as a proxy for competitiveness, it shows both the differences between the North and South of the Eurozone and the differences between the pre-crisis and crisis periods in both areas. Moreover, it demonstrates that the relationship between the competitiveness and unemployment is negative in the North and undetectable in the most of the South. These results indicate that the recent gains in competitiveness can be preserved - and even perhaps extended - without the negative impact on employment. Indeed, in this context the structural reforms are the key.
\end{abstract}

Keywords: competitiveness, productivity, unemployment, Eurozone's north and south

\section{Introduction}

The long term dynamics of the relationship between the competitiveness and the unemployment in the Eurozone, with the emphasis on the North - South differences, is analyzed.

It is today commonly recognized that the restoration (and in fact the improvement) of the competitiveness among the Eurozone members on the Mediterranean littoral is the key for the restoration of the economic health of those countries. And, indeed, the reduction of the unemployment (from its current unprecedented heights) is necessary to restore the political stability which in turn should lead to a restoration of hope and believe in the future prosperity of the common European project.

The effort to restore and improve the competitiveness implies the improvement of the unit labor costs which in turn requires a higher productivity (statistically, the reduction of the wage bill as the share of GDP, measured macroeconomically). On the macroeconomic scale, the productivity can rise, rising the GDP and hence lowering the unit labor costs (ULC) independently on the employment level. Alternatively, the elimination of the low productivity activities rises macro productivity (and reduces the ULC), but leads to the rise of the unemployment.

Distinguishing between these alternatives is important for the Eurozone's (and hence the EU's) future. The first case is, indeed, desirable. In contrast, the second case raises the question of a possible tradeoff between the competitiveness and a full employment in the absence of a possibility of currency devaluation - the tradeoff which threatens the Eurozone's cohesion and stability.

Part II discusses the relevant analytical modelling and reviews some of the existing literature on the relationship between the productivity, competitiveness and unemployment. Data and estimations are provided in Part III. Part IV then discusses the econometric results. Part V concludes.

\section{Analytical Modelling}

Looking at the recent data and using the conventional indicators of competitiveness (real exchange rates, unit labor costs, current account positions), one may argue that the competitiveness in the Eurozone improved, especially in the Mediterranean countries. However, the unemployment in the same countries remains stubbornly high. In fact, the casual look at the data for these countries suggests the negative correlation between the competitiveness and the unemployment after the onset of recession.

To determine the actual relationship between the competitiveness and employment dynamic in different parts of the Eurozone, we compared the dynamics of the labor productivity per person to the unemployment rate (data 
are available from the Eurostat). Following the analysis of di Mauro and Forster (2008), the productivity may be considered a better measure of competitiveness compared to conventional indicators.

There is an extensive economic literature discussing the relationship between the dynamics of productivity and unemployment. (As examples, see Brauninger \& Pannenberg, 2002; Blanchard, Solow, \& Wilson, 1995; Gordon, 1995; Trehan, 2001). The critical review is beyond the scope of this paper. However, it may be useful to mention the main ideas.

Theoretically (assuming the Cobb-Douglas type of the production relationship) an increase in productivity - i.e. an increase in the output per unit of labor - increases the marginal product of at least one, but possibly both, basic inputs (capital and labor). The impact on the employment (or, more precisely, the demand for labor) will then depend on the nature of productivity changes. In "corner" cases, if the change in productivity is entirely embedded in the increases of a marginal product of capital (with no change in the marginal product of labor), the capital will be substituted for labor in production. The demand for labor and hence the employment declines - i.e. the unemployment increases.

Conversely, if the increase in productivity is entirely embedded in the marginal product of labor, the labor will be substituted for capital and the demand for labor increases - i.e. the unemployment may decline.

The "corner" cases are, indeed, the borderline. In reality supported by the historical experience, the increases in productivity increase both marginal products. The actual impact on employment will then depend on the detailed nature of marginal product changes.

Moreover, one may argue that whatever is the mechanism (and results) described above, in a sufficiently long period increases in productivity increase income of factors of production which increases aggregate demand and (based on the historical experience) the demand for labor

This dynamics will lead to an increase in employment - hence a lower unemployment - ceteris paribus, i.e. under stable labor supply conditions. However, the latter is unlikely to remain stable due to changing demographics, social and labor policies etc. which all influence the level and dynamics of reservation wages and hence the labor supply and observed unemployment.

To summarize at this point, the theoretical analysis postulates the increases in productivity can have positive, negative or neutral impacts on employment (and hence on the measured unemployment) depending on detailed circumstances of individual cases (countries).

In this paper we concentrate on the empirical analysis of the relationship between the productivity (measured as productivity per person working) and the unemployment in 12 Eurozone countries (11 founding members plus Greece). There are three questions to be answered. First is the nature of empirically observed relationship between the productivity as a proxy measure for competitiveness and the unemployment in individual countries. Second question is whether there is a difference in this relationship between the precrisis (1999: Q1-2009: Q1) and crisis (2009: Q2-2014: Q2) periods. And the third question is whether there is a difference between the Southern (basically the countries on the Mediterranean littoral plus Ireland) and Northern Eurozone members.

\section{Data and Estimation}

The relationship between the productivity per person (as the proxy for a measure of competitiveness) and the unemployment is estimated individually for the 12 Eurozone countries (11 original members and Greece). In reporting, these countries are divided into two groups: North, composed of Germany, Netherlands, Belgium, Luxembourg, France, Finland and Austria, and South, composed of Italy, Spain, Greece, Portugal and Ireland. The estimates for each country are then divided into two periods: the pre-crisis period

1999: Q1-2009: Q1 and the crisis period 2009: Q2-2014: Q2. (The last date is the last one for which the data were available at the time of estimation.) All data used were obtained from the Eurostat database.

All time series were tested for unit roots in both levels and first differences. The results (not reported here) rejected the unit roots hypothesis for first differences. For levels the results were mixed. This implies that the cointegration estimations would be questionable. (That was confirmed be preliminary tests, all of which rejected the cointegration hypothesis.) Because of the ex ante unclear direction of causality, the VAR approach was considered. However, given the quarterly data frequency the contemporaneous effects cannot be excluded, which implies infeasibility of the VAR approach. Therefore, the SUR (seemingly unrelated regression) approach was selected.

Two equations ( 1 and 2 below) were estimated by SUR for each country and for both pre-crisis and crisis periods. 


$$
\begin{gathered}
\text { Unemployment }=\text { Constant }+\sum_{t=1}^{2} \text { Unemployment }_{t}+\sum_{t=0}^{2} \text { Productivity }_{t} \\
\text { Productivity }^{=} \text {Constant }+\sum_{t=0}^{2} \text { Unemployment }_{t}+\sum_{t=1}^{2} \text { Productivity }_{t}
\end{gathered}
$$

Number of lags was determined by Akaike and Schwartz criteria. Estimations were made in first differences and results are reported in Tables 1-4 (in the Appendix). The coefficients of explanatory variables were summarized by using the SUMMARIZE instruction in the RATS software. Statistically significant coefficients are printed in bold.

\section{Results}

Tables 1 and 2 report the estimates (numbers in parenthesis are the relevant t-statistics) for the South and North respectively for the pre-crisis period 1999: Q1-2009: Q1. For the South estimates show a positive relationship between the productivity and unemployment for Spain (positive estimated coefficient indicates that the increase in productivity increases unemployment) and a negative one for Italy (negative estimated coefficient indicates that the increase in productivity reduces unemployment). In the case of Ireland it is indicated that an increase in unemployment tends to increase the productivity (the relevant coefficient is positive). The constants then indicate whether the underlying productivity and/or unemployment dynamics tend to accelerate (Portugal) or decelerate (Italy). (Remember, estimates are made in first differences.)

\begin{tabular}{|c|c|c|c|c|}
\hline Dependent Variable & Country & Constant & Unemployment Summarized & Productivity Summarized \\
\hline & SPAIN & & & \\
\hline \multirow[t]{2}{*}{ Unemployment } & & 0.018 & 0.898 & 1.163 \\
\hline & & -0.39 & -8.81 & -4.34 \\
\hline \multirow[t]{3}{*}{ Productivity } & & 0.017 & 1.734 & 0.387 \\
\hline & & -0.36 & -10.3 & -1.68 \\
\hline & PORTUGAL & & & \\
\hline \multirow[t]{2}{*}{ Unemployment } & & 0.122 & 0.296 & -0.225 \\
\hline & & -2.06 & -1.42 & -1.75 \\
\hline \multirow[t]{3}{*}{ Productivity } & & 0.35 & -0.266 & -0.136 \\
\hline & & -2.36 & -0.61 & -1.36 \\
\hline & ITALY & & & \\
\hline \multirow[t]{2}{*}{ Unemployment } & & -0.089 & 0.169 & -0.174 \\
\hline & & -2.19 & -0.76 & -2.43 \\
\hline \multirow[t]{3}{*}{ Productivity } & & -0.258 & -0.29 & -1.3 \\
\hline & & -1.97 & -0.53 & -1.85 \\
\hline & IRELAND & & & \\
\hline \multirow[t]{2}{*}{ Unemployment } & & 0.025 & 1.37 & 0.142 \\
\hline & & -0.41 & -7.96 & -1.77 \\
\hline \multirow[t]{3}{*}{ Productivity } & & 0.473 & 3.495 & 0.012 \\
\hline & & -2 & -5.8 & -0.19 \\
\hline & GREECE & & & \\
\hline \multirow[t]{2}{*}{ Unemployment } & & -0.015 & 0.208 & -0.059 \\
\hline & & -0.22 & -0.86 & -0.61 \\
\hline \multirow[t]{2}{*}{ Productivity } & & 0.379 & -0.036 & -0.031 \\
\hline & & -1.89 & -0.07 & -0.4 \\
\hline
\end{tabular}

Table 1. Productivity and unemployment-south: pre-crisis 1999 Q1-2009 Q1

As far as the North is concerned, reductions in unemployment tend to increase the productivity in all countries except the Belgium and Austria. Perhaps more importantly. the increases in productivity tended to reduce unemployment in Netherlands, France, Finland and Austria. Netherlands displays an increasing unemployment trend, albeit marginally. 
Table 2. Productivity and unemployment-north: pre-crisis 1999 Q1-2009 Q1

\begin{tabular}{|c|c|c|c|c|}
\hline Dependent Variable & Country & Constant & Unemployment Summarized & Productivity Summarized \\
\hline & NETHERLANDS & & & \\
\hline \multirow[t]{2}{*}{ Unemployment } & & 0.043 & 0.85 & -0.149 \\
\hline & & -1.98 & -9.21 & -3.24 \\
\hline \multirow[t]{3}{*}{ Productivity } & & 0.133 & -0.162 & -0.057 \\
\hline & & -0.36 & -10.3 & -1.17 \\
\hline & LUXEMBOURG & & & \\
\hline \multirow[t]{2}{*}{ Unemployment } & & 0.025 & 0.693 & -0.029 \\
\hline & & -1.13 & -5.98 & -1.46 \\
\hline \multirow[t]{3}{*}{ Productivity } & & 0.075 & -4.495 & -0.005 \\
\hline & & -0.23 & -2.03 & -0.27 \\
\hline & GERMANY & & & \\
\hline \multirow[t]{2}{*}{ Unemployment } & & 0.009 & 0.869 & -0.076 \\
\hline & & -0.42 & -11.3 & -1.76 \\
\hline \multirow[t]{3}{*}{ Productivity } & & 0.004 & -2.93 & 0.053 \\
\hline & & -0.03 & -4.06 & -1.05 \\
\hline & FRANCE & & & \\
\hline \multirow[t]{2}{*}{ Unemployment } & & 0.036 & 0.78 & -0.294 \\
\hline & & -1.11 & -6.09 & -3.3 \\
\hline \multirow[t]{3}{*}{ Productivity } & & 0.056 & -0.913 & 0.059 \\
\hline & & -0.78 & -3.03 & -0.59 \\
\hline & FINLAND & & & \\
\hline \multirow[t]{2}{*}{ Unemployment } & & 0.003 & 0.599 & -0.106 \\
\hline & & -0.14 & -3.96 & -3.56 \\
\hline \multirow[t]{3}{*}{ Productivity } & & -0.093 & -5.708 & -0.039 \\
\hline & & -0.37 & -4.29 & -1.29 \\
\hline & BELGIUM & & & \\
\hline \multirow[t]{2}{*}{ Unemployment } & & 0.006 & -0.09 & -0.24 \\
\hline & & -0.1 & -0.36 & -1.65 \\
\hline \multirow[t]{3}{*}{ Productivity } & & 0.055 & -0.08 & -0.246 \\
\hline & & -0.64 & -0.25 & -1.62 \\
\hline & AUSTRIA & & & \\
\hline \multirow[t]{2}{*}{ Unemployment } & & 0.074 & 0.462 & -0.247 \\
\hline & & -2.12 & -2.57 & -3.38 \\
\hline \multirow[t]{2}{*}{ Productivity } & & 0.155 & -0.369 & 0.004 \\
\hline & & -2.5 & -1.13 & -0.05 \\
\hline
\end{tabular}

The comparison between the North and South indicates the divergent dynamics even in the pre-crisis period. The negative relationships between the productivity and unemployment (in either direction) indicates a capacity for a "positive circle' - increases in productivity (i.e. the competitiveness) reduce unemployment and declining unemployment enhances competitiveness. This relationship seemed to be common in the North but is basically missing in the South - except in Italy. Indeed, it might contribute to a different impact of the globalization phenomena on North and South, observable even in the pre-crisis period.

Tables 3 and 4 provide estimated results for the South and North respectively for the crisis period 2009: Q2-2014: Q2. Positive relationship between the unemployment and productivity (i.e. an increase in unemployment increases productivity) is indicated for Portugal and Spain. However, both Spain and Italy display an increase in secular productivity trends. For the rest of the "South" countries there appear to be no statistically significant relationship between the productivity and unemployment in the crisis period. 
Table 3. Productivity and unemployment-south: crisis 1999 Q2-2014 Q2

\begin{tabular}{|c|c|c|c|c|}
\hline Dependent Variable & Country & Constant & Unemployment Summarized & Productivity Summarized \\
\hline & SPAIN & & & \\
\hline \multirow[t]{2}{*}{ Unemployment } & & -0.572 & 0.091 & 1.743 \\
\hline & & -3.4 & -0.61 & -4.41 \\
\hline \multirow[t]{3}{*}{ Productivity } & & 0.535 & 0.961 & 0.768 \\
\hline & & -3.71 & -4.62 & -2.12 \\
\hline & PORTUGAL & & & \\
\hline \multirow[t]{2}{*}{ Unemployment } & & 0.015 & 0.822 & -0.146 \\
\hline & & -0.17 & -5.08 & -0.81 \\
\hline \multirow[t]{3}{*}{ Productivity } & & 0.35 & 1.284 & -0.24 \\
\hline & & -1.86 & -2.53 & -1.94 \\
\hline & ITALY & & & \\
\hline \multirow[t]{2}{*}{ Unemployment } & & 0.128 & 0.384 & -0.223 \\
\hline & & -1.58 & -1.68 & -1.76 \\
\hline \multirow[t]{3}{*}{ Productivity } & & 0.345 & -0.023 & -1.34 \\
\hline & & -2.07 & -0.04 & -1.77 \\
\hline & IRELAND & & & \\
\hline \multirow[t]{2}{*}{ Unemployment } & & -0.115 & 0.448 & 0.168 \\
\hline & & -1.41 & -3.79 & -1.44 \\
\hline \multirow[t]{3}{*}{ Productivity } & & -0.066 & -0.812 & 0.357 \\
\hline & & -0.3 & -1.5 & -3.26 \\
\hline & GREECE & & & \\
\hline \multirow[t]{2}{*}{ Unemployment } & & 0.025 & 0.93 & -0.067 \\
\hline & & -0.14 & -5.75 & -0.62 \\
\hline \multirow[t]{2}{*}{ Productivity } & & 0.034 & 0.043 & 0.035 \\
\hline & & -0.09 & -0.86 & -0.32 \\
\hline
\end{tabular}

In the North (Table 4) the reduction in unemployment increases productivity (i.e. the estimated coefficient has a statistically significant negative sign) in Luxembourg, Germany, France and Finland, whereas an increase in productivity reduces unemployment in Germany, France and Finland. No statistically significant relationship between these two variables was detected in Netherlands and Belgium. Austria, where an increase in unemployment indicate an increase in productivity (statistically significant positive coefficient) appears to be the Northern outlier.

Table 4. Productivity and unemployment-north: crisis 2009 Q2-2014 Q2

\begin{tabular}{|c|c|c|c|c|}
\hline Dependent Variable & Country & Constant & Unemployment Summarized & Productivity Summarized \\
\hline & NETHERLANDS & & & \\
\hline \multirow{2}{*}{ Unemployment } & & 0.083 & 0.485 & -0.151 \\
\hline & & -1.47 & -2.11 & -1.26 \\
\hline \multirow[t]{3}{*}{ Productivity } & & -0.085 & 0.437 & -0.143 \\
\hline & & -0.57 & -0.73 & -2.19 \\
\hline & LUXEMBOURG & & & \\
\hline \multirow[t]{2}{*}{ Unemployment } & & 0.018 & 0.53 & -0.101 \\
\hline & & -0.54 & -2.42 & -1.52 \\
\hline \multirow[t]{3}{*}{ Productivity } & & 0.006 & -2.18 & 0.002 \\
\hline & & -0.03 & -2.07 & -0.04 \\
\hline & GERMANY & & & \\
\hline \multirow[t]{2}{*}{ Unemployment } & & -0.05 & 0.192 & -0.277 \\
\hline & & -2.33 & -1.35 & -8.16 \\
\hline \multirow[t]{3}{*}{ Productivity } & & -0.182 & -5.123 & -0.126 \\
\hline & & -1.22 & -5.74 & -3.97 \\
\hline & FRANCE & & & \\
\hline \multirow[t]{2}{*}{ Unemployment } & & 0.174 & 0.104 & -0.657 \\
\hline & & -3.99 & -0.55 & -4.67 \\
\hline Productivity & & 0.378 & -1.183 & -0.376 \\
\hline
\end{tabular}




\begin{tabular}{|c|c|c|c|c|}
\hline & & -4.12 & -2.59 & -4.16 \\
\hline & FINLAND & & & \\
\hline \multirow[t]{2}{*}{ Unemployment } & & 0.033 & 0.502 & -0.233 \\
\hline & & -1.69 & -5.12 & -6.67 \\
\hline \multirow[t]{3}{*}{ Productivity } & & 0.297 & -7.202 & -0.131 \\
\hline & & -1.73 & -5.6 & -5.22 \\
\hline & BELGIUM & & & \\
\hline \multirow[t]{2}{*}{ Unemployment } & & 0.088 & 0.418 & -0.55 \\
\hline & & -1.21 & -1.46 & -1.89 \\
\hline \multirow[t]{3}{*}{ Productivity } & & 0.121 & 0.005 & 0.074 \\
\hline & & -2.22 & -0.01 & -0.46 \\
\hline & AUSTRIA & & & \\
\hline \multirow[t]{2}{*}{ Unemployment } & & 0.001 & 0.411 & 0.004 \\
\hline & & -0.02 & -1.4 & -0.04 \\
\hline \multirow[t]{2}{*}{ Productivity } & & 0.028 & 1.737 & -0.405 \\
\hline & & -0.51 & -4.18 & -5.58 \\
\hline
\end{tabular}

The estimated results indicate that divergent tendencies between the North and South, detected in the pre-crisis period, continued in the crisis period. The North (except Austria) appears to ride off the impact of the recession more successfully than South. A positive relationship between the unemployment and productivity in Portugal and Spain in the crisis period indicates that an observed improvement in competitiveness in those two countries was achieved via a liquidation of marginal low productivity activities - which would explain both a rise in the unemployment and an increase in the productivity on a macroeconomic scale.

\section{Conclusion}

Estimates presented above confirm the existence of rising divergences between the Eurozone's North and South. Indeed, if not addressed, these divergences make a stabilization oriented monetary policy increasingly difficult and may present the greatest danger to the cohesion and perhaps the existence of the Eurozone itself.

However, our analysis indicates some silver linings. The negative relationship between the productivity (the proxy for the competitiveness) and unemployment, observed in the majority of Northern countries (including France, which some today call "the sick man of Europe") indicate that those countries may be well positioned in the future globalized world economy.

Second, the lack of observable relationship between the competitiveness proxied by the productivity and the unemployment in most of Southern countries (except Portugal and Spain) indicate that their recent gains in competitiveness can be preserved - and even perhaps extended - without the negative impact on employment.

Indeed, in this context the structural reforms are the key. Their successful implementation requires a cooperation between the EU and national authorities. Eurozone and the whole EU have a future - but it must be worked on.

\section{References}

Blanchard, O., Solow, R., \& Wilson, B. A. (1995). Productivity and Unemployment. Mimeo: MIT.

Brauninger, M., \& Pannenberg, M. (2002). Unemployment and Productivity Growth. Economic Modelling, 19, 105-120. http://dx.doi.org/10.1016/S0264-9993(00)00065-1

Di Mauro, F., \& Forster, K. (2008). Globalization and Competitivenes of the Euro Area. ECB Occasional Paper No. 97, September.

Gordon, R. J. (1995). Is There a Tradeoff Between Unemployment and Productivity Growth? NBER Working Paper No. 5081.

Trehan, B. (2001). Unemployment and Productivity. FRBSF Economic Letter. Number 2001-28, October $12^{\text {th }}$.

\section{Copyrights}

Copyright for this article is retained by the author(s), with first publication rights granted to the journal.

This is an open-access article distributed under the terms and conditions of the Creative Commons Attribution license (http://creativecommons.org/licenses/by/3.0/). 